\title{
Agro-biološka raznolikost slovenskih ekotipov in standardnih sort navadne pasje trave (Dactylis glomerata L.): primerjava in agronomska vrednost
}

\author{
Jure ČOP ${ }^{1,2}$, Klemen ELER ${ }^{1}$
}

Received December 27, 2019; accepted January 11, 2020.

Delo je prispelo 27. decembra 2019, sprejeto 11. januarja 2020.

\begin{abstract}
Agro-biološka raznolikost slovenskih ekotipov in standardnih sort navadne pasje trave (Dactylis glomerata L.): primerjava in agronomska vrednost

Izvleček: Opisovanje in vrednotenje akcesij, na primer ekotipov kulturnih rastlin, je temeljna naloga kmetijske rastlinske genske banke. S poljskim poskusom smo v letih 2015-2019 raziskovali agro-biološko raznolikost 15 slovenskih ekotipov (skupina 1) in 7 standardnih sort (skupina 2) navadne pasje trave (Dactylis glomerata L.) s poudarkom na primerjavi teh dveh skupin. Ocenili smo tudi agronomsko vrednost ekotipov glede na sorte. Zasnova poskusa je bila naključni blok s 3 ponovitvami. Vsak ekotip oziroma sorta je bila zastopana z 20 posameznimi rastlinami na ponovitev. Med obravnavanimi entitetami so bile ugotovljene značilne razlike v vseh preučevanih agro-bioloških lastnostih $(p<0,001)$. Značilne razlike so bile ugotovljene tudi pri primerjavi skupin $(p<0,001)$ razen v okuženosti z listnimi boleznimi ( $p=0,113)$. Pri tem so bile sorte z agronomskega vidika boljše kot ekotipi. Raznolikost znotraj populacij je bila pri slovenskih ekotipih večja kot pri standardnih sortah, na njo je odpadel tudi večji del skupne variance ekotipov. Analiza glavnih komponent (AGK) na vseh preučevanih lastnostih je pokazala izrazito razlikovanje ekotipov od sort in večjo podobnost med sortami kot med ekotipi. Pri slednjih se kot rezultat AGK kažeta dve podskupini, kar pa ne moremo razložiti z izvorom ekotipov.

Ključne besede: genska banka; populacije; opisovanje; vrednotenje
\end{abstract}

Agro-biological diversity of Slovene ecotypes and standard varieties of cocksfoot (Dactylis glomerata L.): comparison and agronomic value

Abstract: Characterisation and evaluation of accessions, e.g. ecotypes of cultivated plants, are the primary task of each agricultural gene bank. In a field experiment, agro-biological diversity and agronomic value of 15 Slovene ecotypes (group 1) and 7 standard varieties (group 2) of cocksfoot (Dactylis glomerata L.) were investigated during the 2015-2019 period. A particular emphasis was given to the comparison of the two groups. The spaced plant experiment with 20 single plants of each treatment entity per replicate was arranged in a randomized complete block design with three replicates. Significant differences among investigated entities were confirmed for all agro-biological traits $(p<0.001)$. The same holds when the groups were compared $(p<0.001)$ except for the infection with leaf fungal diseases $(p=0.113)$.Considering these differences varieties possessed higher agronomic value than ecotypes. In general, the intra-population diversity of Slovene ecotypes was higher than that of standard varieties and represented a higher portion of the ecotype complete variance. Principal component analysis (PCA) of all investigated traits showed a distinctive difference between ecotypes and varieties and higher similarity within the variety group than within the ecotype group. PCA also showed that the ecotypes can be separated into two subgroups, which however cannot be explained by the characteristics of ecotype origin.

Key words: gene bank; populations; characterization; evaluation

1 Univerza v Ljubljani, Biotehniška fakulteta, Oddelek za agronomijo, Jamnikarjeva 101, SI-1000, Ljubljana, Slovenija

2 Korespondenčni avtor, e-naslov: jure.cop@bf.uni-lj.si 


\section{UVOD}

Navadna pasja trava (Dactylis glomerata L.) je trajnica zmernega podnebnega pasu, ki jo sestavlja več različno ploidnih podvrst. Na travinju v Evropi in širše prevladuje antropofilna, tetraploidna $(2 \mathrm{n}=4 \mathrm{x}=28)$ oblika (Lindner in Garcia, 1997; Tuna in sod., 2004). Enako velja tudi za situacijo $\mathrm{z}$ navadno pasjo travo v Sloveniji (Martinčič in sod., 2007).

Navadna pasja trava je konkurenčna in na stres tolerantna vrsta, zato je pomembna za pridelavo krme na rodovitnih travniških tleh, $\mathrm{v}$ travno-deteljnih mešanicah na njivah in na manj rodovitnih travniških tleh, kjer se redno pojavlja suša. Priporoča se za setev v dveletnih do štiriletnih mešanicah $\mathrm{z}$ ljuljkami, ker pripomore $\mathrm{k}$ boljši in zanesljivejši pridelavi krme $\mathrm{v}$ drugi polovici pridelovalnega obdobja (Suter in sod., 2013; AGFF, 2017).

Krmna vrednost navadne pasje trave je $\mathrm{v}$ zgodnjih razvojnih fazah zelo velika. $\mathrm{V}$ primerjavi $\mathrm{z}$ drugimi kakovostnimi travami izstopa $\mathrm{z}$ veliko vsebnostjo surovih beljakovin (DLG, 1997). Tako je na primer v zadnji dekadi aprila povprečna dveletna vsebnost surovih beljakovin v zelinju navadne pasje trave znašala $219 \mathrm{~g} \mathrm{~kg}^{-1}$ sušine, pri trpežni ljuljki pa le $171 \mathrm{~g} \mathrm{~kg}^{-1}$ sušine (Čop in sod., 2009). Slabšanje kakovosti zelinja s staranjem poganjkov je agronomska pomanjkljivost navadne pasje trave, ki se ji lahko delno izognemo s primerno zgodnjo rabo. Uspešnost pridelave krme $\mathrm{z}$ navadno pasjo travo, tako $\mathrm{v}$ smislu prilagajanja okoljskim in pridelovalnim razmeram kot zagotavljanja ustrezne kakovosti krme, je v veliki meri odvisna od sort, pa tudi od ekotipov, ki se uporabljajo za žlahtnjenje.

Agro-biološke lastnosti trav, s katerimi se ukvarjamo pri ocenjevanju ekotipov, sort v potrjevanju (test razločljivosti, izenačenosti in nespremenljivosti - RIN-test) in žlahtnjenju, so pomembne tako s stališča količine in kakovosti pridelka kot trajanja pridelave (trpežnosti). Ocenjujemo agro-biološke lastnosti, kot na primer višina stebel, pokončnost rasti (habitus), začetek latenja, tvorba socvetij med rastno sezono, regeneracija po defoliaciji, okuženost $\mathrm{z}$ boleznimi, trpežnost idr. (IPGRI, 1985; UPOV, 2002). Kakovostna sorta navadne pasje trave ne sme biti previsoka. Mora biti pokončne rasti in pozna $\mathrm{v}$ razvoju, imeti mora slabo izraženo determinantno rast ter dobro regeneracijo, odpornost proti boleznim in trpežnost.

Z raziskavo smo želeli ugotoviti: (1) kakšno je variiranje preučevanih agro-bioloških lastnosti med in znotraj ekotipov in standardnih sort, (2) kakšna je agronomska vrednost ekotipov glede na preučevane lastnosti v primerjavi s standardnimi sortami in (3) ali izvor ekotipov (geografska lega, talne lastnosti, pridelovalne razme- re) oziroma žlahtnjenje sort povzroči njihovo grupiranje ob upoštevanju vseh preučevanih lastnosti obenem.

\section{MATERIALI IN METODE}

\subsection{EKOTIPI IN STANDARDNE SORTE}

V raziskavo je bilo vključenih 15 slovenskih ekotipov in 7 standardnih sort navadne pasje trave. Ekotipe smo nabirali v obliki semena na trajnih travnikih v nižinskih, gričevnatih in hribovitih predelih Slovenije v letih od 2007 do 2014. Vsi so vključeni v rastlinsko gensko banko Slovenije. Sorte smo pridobili neposredno od žlahtniteljev oziroma pooblaščenih semenarskih hiš. Pri izboru sort smo upoštevali priporočili inštitucij, ki izvajata RIN-teste, tj. Centralnega inštituta za kontrolo in testiranje v Bratislavi (Ústredný kontrolný a skúšobný ústav polnohospodársky v Bratislave, Slovaška) in Raziskovalnega centra za testiranje sort v Słupia Wielka (Centralny Osrodek Badania Odmian Roslin Uprawnych, Poljska). Upoštevali smo tudi pridelovalno vrednost in ekološke lastnosti sort. Podatki o izvoru ekotipov in sort so $\mathrm{v}$ Preglednici 1.

\subsection{OPIS POSKUSA}

Poljski poskus je potekal po standardiziranem postopku na poskusnem polju Oddelka za agronomijo Biotehniške fakultete v Ljubljani od leta 2015 do leta 2019. Zasnovan je bil v naključnem bloku s tremi ponovitvami. Vsak ekotip oziroma sorto v posamezni ponovitvi je sestavljalo 20 rastlin, ločeno posajenih na razdaljo $50 \times$ $70 \mathrm{~cm}$. Vseh rastlin v poskusu je bilo 1320. Letna oskrba poskusa je zajemala spomladansko gnojenje z NPK 15:15:15, dve dognojevanji s kalcijevim amonijevim nitratom (KAN, $27 \% \mathrm{~N}$ ), tri košnje in dve okopavanji. Letni odmerek hranil je znašal $200 \mathrm{~kg} \mathrm{~N} v$ treh obrokih, $80 \mathrm{~kg} \mathrm{P}_{2} \mathrm{O}_{5}$ in $80 \mathrm{~kg} \mathrm{~K}_{2} \mathrm{O} \mathrm{ha}^{-1}$. Višina rezi ob košnji je bila od 5 do $7 \mathrm{~cm}$.

Na poskusnem polju se nahajajo rjava aluvialna tla na karbonatnem pesku in produ. $\mathrm{V}$ zgornji $30 \mathrm{~cm}$ plasti je meljasta ilovica, pod njo je do globine $110 \mathrm{~cm}$ zmerno oglejena meljasto glinasta ilovica. Na poskusnem polju je postavljena cevna drenaža, po kateri odteka padavinska voda, ki pronica skozi tla. Na začetku poskusa so bila tla v zgornji $22 \mathrm{~cm}$ plasti nevtralna $\left(\mathrm{pH} 6,9 \mathrm{v} \mathrm{CaCl}_{2}\right)$ ter dobro preskrbljena s fosforjem (137 $\mathrm{mg} \mathrm{P}_{2} \mathrm{O}_{5} \mathrm{~kg}^{-1} \mathrm{tal}$ ) in srednje dobro s kalijem (172 $\left.\mathrm{mg} \mathrm{K}_{2} \mathrm{O} \mathrm{kg}^{-1} \mathrm{tal}\right)$.

Vremenske razmere so bile v poskusnem obdobju razmeroma ugodne za rast krmnih trav. Poletna suša, ki je običajna v pretežnem delu Slovenije, je bila izrazitejša 
Preglednica 1: Podatki o izvoru ekotipov in standardnih sort navadne pasje trave, vključenih v raziskavo. Dodani so podatki o rastišču in rabi za ekotipe in podatki o zgodnosti za sorte.

Table 1: Data on the origin of ecotypes and standard varieties of cocksfoot included in the research. Data on the habitat and number of harvests for ecotypes and development earliness for the varieties are added.

\begin{tabular}{|c|c|c|c|c|c|c|c|}
\hline $\begin{array}{l}\text { Ekotip/ } \\
\text { Sorta }\end{array}$ & $\begin{array}{l}\text { Pokrajina/ } \\
\text { Država }\end{array}$ & $\begin{array}{l}\text { Lokacija/ } \\
\text { Žlahtnitelj }\end{array}$ & $\begin{array}{l}\text { Zemljepisna } \\
\text { širina }(\mathrm{S})\end{array}$ & $\begin{array}{l}\text { Zemljepisna } \\
\text { dolžina (V) }\end{array}$ & $\begin{array}{l}\text { Nadmorska } \\
\text { višina }(\mathrm{m})\end{array}$ & $\begin{array}{l}\text { Vlažnost } \\
\text { rastišča }\end{array}$ & $\begin{array}{l}\text { Košnja } \\
\text { (število) }\end{array}$ \\
\hline $\operatorname{Dg} 01 / 14$ & Bela krajina & Špeharji & $45^{\circ} 26^{\prime}$ & $15^{0} 8^{\prime}$ & 278 & suho & 1 \\
\hline $\operatorname{Dg} 02 / 14$ & Bela krajina & Marindol & $45^{0} 30^{\prime}$ & $15^{0} 19^{\prime}$ & 238 & suho & 2 \\
\hline $\operatorname{Dg} 03 / 14$ & Bela krajina & Semič & $45^{0} 39^{\prime}$ & $15^{0} 6^{\prime}$ & 446 & polsuho & $1-2$ \\
\hline $\operatorname{Dg} 04 / 14$ & Zasavje & Padež & $46^{0} 3^{\prime}$ & $15^{0} 0^{\prime}$ & 748 & suho & 1 \\
\hline $\operatorname{Dg} 01 / 13$ & Dolenjska & Veliko Mlačevo & $45^{\circ} 56^{\prime}$ & $14^{\circ} 40^{\prime}$ & 328 & sr. vlažno & $2-3$ \\
\hline $\operatorname{Dg} 04 / 13$ & Dolenjska & Zdenska vas & $45^{\circ} 49^{\prime}$ & $14^{\circ} 42^{\prime}$ & 441 & polsuho & $1-2$ \\
\hline $\operatorname{Dg} 05 / 13$ & Dolenjska & Kompolje & $45^{\circ} 48^{\prime}$ & $14^{\circ} 44^{\prime}$ & 463 & polsuho & $1-2$ \\
\hline $\operatorname{Dg} 08 / 13$ & Dolenjska & Ambrus & $45^{\circ} 49^{\prime}$ & $14^{\circ} 48^{\prime}$ & 355 & sr. vlažno & $2-3$ \\
\hline $\operatorname{Dg} 09 / 13$ & Zasavje & Ribče & $46^{\circ} 5^{\prime}$ & $14^{\circ} 46^{\prime}$ & 272 & polsuho & $1-2$ \\
\hline $\operatorname{Dg} 13 / 13$ & Gorenjska & Jamnik & $46^{\circ} 16^{\prime}$ & $14^{\circ} 12^{\prime}$ & 830 & polsuho & $1-2$ \\
\hline $\operatorname{Dg} 14 / 13$ & $\begin{array}{l}\text { Osrednja Slove- } \\
\text { nija }\end{array}$ & Črnuče & $46^{\circ} 56^{\prime}$ & $14^{\circ} 26^{\prime}$ & 298 & sr. vlažno & $2-3$ \\
\hline $\operatorname{Dg} 16 / 13$ & $\begin{array}{l}\text { Osrednja Slove- } \\
\text { nija }\end{array}$ & $\begin{array}{l}\text { Gorenja Brezo- } \\
\text { vica }\end{array}$ & $45^{\circ} 56^{\prime}$ & $14^{\circ} 26^{\prime}$ & 481 & suho & 1 \\
\hline $\operatorname{Dg} 19 / 13$ & Zasavje & Podkum & $46^{\circ} 4^{\prime}$ & $15^{\circ} 2^{\prime}$ & 750 & suho & 1 \\
\hline Dc 06/07 & Notranjska & Travnik & $45^{\circ} 41^{\prime}$ & $14^{\circ} 35^{\prime}$ & 703 & sr. vlažno & 2 \\
\hline Dg 03/07 & Notranjska & Travna Gora & $45^{\circ} 44^{\prime}$ & $14^{\circ} 38^{\prime}$ & 891 & polsuho & 2 \\
\hline Trerano & Nemčija & $\begin{array}{l}\text { Feldsaaten Freu- } \\
\text { denberger }\end{array}$ & zelo zgodna sorta & & & & \\
\hline Beluga & Švica & DSP AG & zelo pozna sorta & & & & \\
\hline Reda & Švica & DSP AG & zgodna sorta & & & & \\
\hline Intensiv & Nizozemska & Barenbrug & $\begin{array}{l}\text { srednje zgodna } \\
\text { do pozna sorta }\end{array}$ & & & & \\
\hline Dascada & Nizozemska & Barenbrug & $\begin{array}{l}\text { zgodna do sredn- } \\
\text { je zgodna sorta }\end{array}$ & & & & \\
\hline Barlegro & Nizozemska & Barenbrug & zelo pozna sorta & & & & \\
\hline Padania & Italija & CREA-ZA Lodi & $\begin{array}{l}\text { srednje zgodna } \\
\text { sorta }\end{array}$ & & & & \\
\hline
\end{tabular}

v letih 2016, 2017 in 2019. Najbolj je na to vplivala neugodna časovna razporeditev padavin med rastno sezono, manj pa tudi povečana temperatura zraka. Tako je bilo v skrajnih primerih $151 \mathrm{~mm}$ manj padavin med majem in avgustom 2017 in $4,4{ }^{\circ} \mathrm{C}$ višja povprečna temperatura zraka v juniju 2019 kot v referenčnem obdobju 19812010.

\subsection{MERITVE IN OCENJEVANJE AGRO- BIOLOŠKIH LASTNOSTI}

V posameznih letih smo opravili meritve višine ra- stlin in šest ocenjevanj agro-bioloških lastnosti. Pri tem smo upoštevali navodila Mednarodnega inštituta za rastlinske genske vire (IPGRI, 1985) in Mednarodne zveze za zaščito novih rastlinskih sort (UPOV, 2002). Višino poganjkov po posameznih šopih smo merili v maju, ko je bila večina poganjkov v fazi zorenja plodov. Upoštevali smo dolžino od osnove do vrha socvetja večine poganjkov v šopu. Ocenjevali smo ob pomoči petstopenjske lestvice, razen pri prisotnosti generativnih poganjkov v jeseni in okuženosti z listnimi boleznimi. V prvem primeru smo uporabili dvostopenjsko lestvico, $\mathrm{v}$ drugem pa devetstopenjsko. Habitus pomeni izraženost pokončne rasti poganjkov in sicer je 1 ležeča rast (prostratum) in 
5 pokončna rast (erektum). Začetek latenja je razvojna faza trav, ki jo je najlažje določiti in se uporablja za oceno zgodnosti. To ocenjevanje smo izvedli v časovnem obdobju dveh mesecev v petih terminih (pred 15. aprilom, 15. in 22. aprila, 9. in 23. maja). Faza začetka latenja je nastopila, ko so se v šopu pojavili trije poganjki s socvetjem. Regeneracijo po košnji smo ocenili v juliju, ko visoka temperatura zraka in pogosto tudi suša poslabšata tvorbo novih listov, ki pomeni začetek nove rasti [ocene: 1 (slaba) do 5 (zelo dobra regeneracija)]. Tendenco tvorbe generativnih poganjkov izven sezone generativne rasti, smo ocenili konec septembra $\mathrm{z}$ binarnim popisom prisotnosti oziroma odsotnosti le-teh po posameznih šopih. Vigor rastlin smo ocenili konec pete rastne sezone, $s$ čimer smo dobili posredno oceno trpežnosti [ocene: 1 (slab) do 5 (zelo dober vigor)]. Okuženost listov z glivičnimi boleznimi, med katerimi so prevladovale okužbe z glivami rodu Puccinia, smo ocenili v začetku avgusta [ocene: 1 (< $10 \%)$ do 9 (75-100 \% okuženost)].

\subsection{STATISTIČNA OBDELAVA}

Raznolikost preučevanih agro-bioloških lastnosti med in znotraj ekotipov in standardnih sort je prikazana z grafom za razpršenost oziroma $\mathrm{z}$ grafi za frekvenčno porazdelitev podatkov. Okvir $z$ ročaji je bil uporabljen pri zvezni spremenljivki za višino rastlin, stolpčni grafi pa pri ordinalnih spremenljivkah za vse druge lastnosti. Razlika v višini rastlin med posameznimi obravnavanimi entitetami (ekotipi in standardne sorte) ter med skupino ekotipov in skupino sort je bila testirana $\mathrm{z}$ analizo variance, razlike $\mathrm{v}$ drugih lastnostih pa s Kruskal-Wallisovim $\mathrm{H}$ testom. Primerjava ekotipov in standardnih sort po vseh parametrih hkrati je bila narejena $\mathrm{z}$ analizo glavnih komponent, pri čemer smo zaradi večinoma ordinalnih spremenljivk uporabili polihorično korelacijo med spremenljivkami. Analize smo opravili v statističnem programskem okolju R (R Core Team, 2019). Za izris stolpčnih grafov ordinalnih spremenljivk smo uporabili knjižnico »likert«.

\section{REZULTATI Z RAZPRAVO}

\subsection{AGRO-BIOLOŠKA RAZNOLIKOST EKOTIPOV IN STANDARDNIH SORT}

Primerjava obravnavanih entitet navadne pasje trave je pokazala, da so med njimi statistično značilne razlike v vseh preučevanih agro-bioloških lastnostih $(p<0,001)$. Enako velja za primerjavo skupine slovenskih ekotipov s skupino standardnih sort $(p<0,001)$ razen pri okuženosti listov z boleznimi, kjer razlika ni značilna $(p=0,113)$.

$\mathrm{V}$ agronomskem smislu so bile sorte izrazito boljše od ekotipov v treh lastnostih, ki so zelo pomembne za količino in kakovost pridelka ter trajanje pridelave. $\mathrm{V}$ primerjavi z ekotipi so sorte rastle izrazito bolj pokončno, se počasneje razvijale in dalj časa ohranjale rastno kondicijo (Slike 2, 3 in 6). Rastline standardnih sort so tudi bolje regenerirale po defoliaciji in razvile manj generativnih poganjkov (Sliki 4 in 5), vendar prednost sort pred ekotipi $\mathrm{v}$ teh dveh lastnostih ni bila tako izrazita kot pri prvih treh. V preostalih dveh lastnostih - višini generativnih poganjkov in okuženosti listov z glivičnimi boleznimi - so si bile sorte in ekotipi podobni (Sliki 1 in 7). Za višino poganjkov to velja kljub značilni razliki med skupinama, ki je posledica zgolj treh značilno manjših ekotipov od povprečne višine sort. Navedene razlike med ekotipi in sortami so pričakovane, zlasti zato, ker smo za standard izbrali najboljše sorte. Te pa so praviloma boljše od ekotipov oziroma izvornega selekcijskega materiala (Fehr, 1991).

Pri naši primerjavi ekotipov in standardnih sort ni bilo nobenega izjemnega ekotipa pri katerikoli lastnosti, čeprav tak primer navajajo Boller in sod. (2009). Pri mnogocvetni ljuljki so namreč ugotovili večjo pridelovalno vrednost izbranih švicarskih ekotipov v primerjavi s sortami.

\subsection{ZNOTRAJ POPULACIJSKA RAZNOLIKOST EKOTIPOV IN STANDARDNIH SORT}

Znotraj populacijska raznolikost $\mathrm{v}$ preučevanih lastnostih je bila izražena tako pri ekotipih kot sortah. Vendar so bile populacije ekotipov izrazito bolj raznolike glede habitusa, regeneracije po defoliaciji, izvensezonske tvorbe generativnih poganjkov in vigorja (Slike 2, 4, 5 in 6). V primerjavi z večino sort je bila znotrajpopulacijska raznolikost ekotipov tudi večja glede zgodnosti razvoja in okuženosti z listnimi boleznimi (Sliki 3 in 7). Znotrajpopulacijska raznolikost $\mathrm{v}$ višini generativnih poganjkov je bila podobna pri obeh skupinah (Slika 1).

Ker je navadna pasja trava alogamna vrsta, so populacije ekotipov in sort genetsko - s tem pa tudi fenotipsko - precej raznolike. Vendar je ta raznolikost izrazitejša pri ekotipih, ker naravna selekcija poteka manj usmerjeno kot odbira pri žlahtnjenju. Raznolikost v preučevanih lastnostih znotraj ekotipov je bila na splošno tudi večja od raznolikosti med samimi ekotipi. Enake ugotovitve glede genetske in fenotipske raznolikosti navajajo Last in sod. (2011) ter Xie in sod. (2012) za ekotipe navadne pasje trave, Bolaric in sod. (2005) za ekotipe trpežne ljuljke ter Pagnotta in sod. (2011) za ekotipe črne detelje. Ve- 


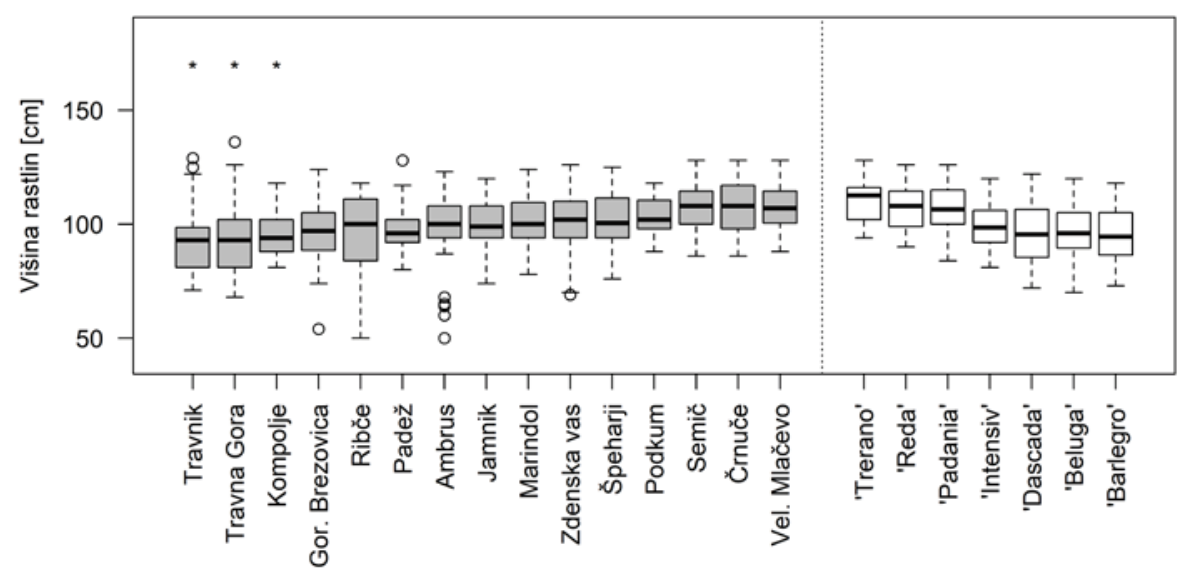

Slika 1: Razpršenost višine 20 rastlin navadne pasje trave po posameznih ekotipih (označeni so z lokacijo) in standardnih sortah, prikazana z okvirji z ročaji. Meritev je bila opravljena 30. maja 2017. Opomba: Simbol * označuje ekotipe, ki se značilno razlikujejo od povprečja standardnih sort.

Figure 1: Box-plot for the height distribution of 20 cocksfoot plants by individual ecotypes (denoted by location name) and standard varieties. The measurement was conducted on May 30 2017. Note: Symbol * marks ecotypes which differed significantly from the average height of varieties.

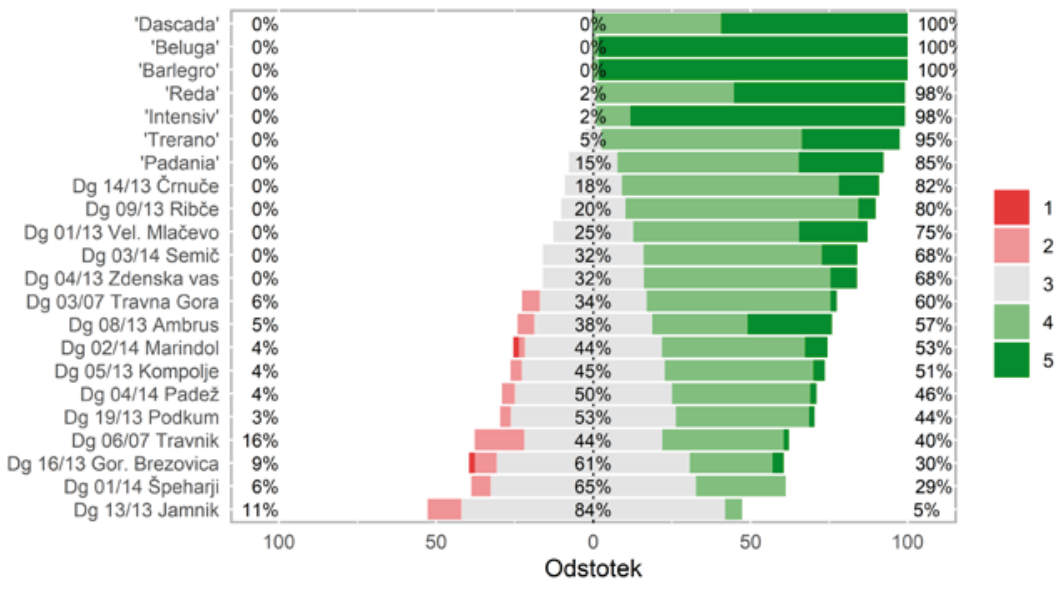

Slika 2: Pogostnostna porazdelitev ocen habitusa po posameznih ekotipih in standardnih sortah navadne pasje trave $(n=20)$. Ocenjevanje je bilo opravljeno 23. maja 2016. Ocene: 1 (ležeča rast) do 5 (pokončna rast).

Figure 2: Frequency distribution of the habitus estimates by individual ecotypes and standard varieties of cocksfoot $(n=20)$. The estimation was conducted on May 23 2016. Estimates: 1 (prostrate growth) to 5 (erect growth).

lika genetska raznolikost med ekotipi je bolj redka kot znotraj ekotipov in je predvsem pogojena $\mathrm{z}$ geografsko oddaljenostjo izvora ekotipov (McGrath, 2008; Last in sod., 2013), kar povečuje razlike v rastnih razmerah in zmanjšuje prenašanje genov med oddaljenimi skupinami rastlin.

Genetska raznolikost vrst, ki se na travinju izraža tudi $\mathrm{v}$ raznolikosti ekotipov, je bistvenega pomena za vitalnost ekosistemov, pri kulturnih rastlinah pa tudi za žlahtniteljski napredek pri vzgoji novih sort. Pri sortah namreč hitro pride do izgube redkih alelov, prisotnih $\mathrm{v}$ naravnih ali polnaravnih populacijah, zato vključevanje samo teh v žlahtnjenje zmanjša možnosti za uspeh (Boller in Greene, 2010).

\subsection{MULTIVARIATNA PRIMERJAVA EKOTIPOV IN STANDARDNIH SORT}

Analiza glavnih komponent, v katero so bile vključene vse preučevane spremenljivke, je pokazala, da prvi dve glavni komponenti pojasnjujeta večino (79,8 \%) variabilnosti obravnavanih entitet. Pokazala je tudi, da obstaja zelo jasno razlikovanje med populacijami ekotipov in 


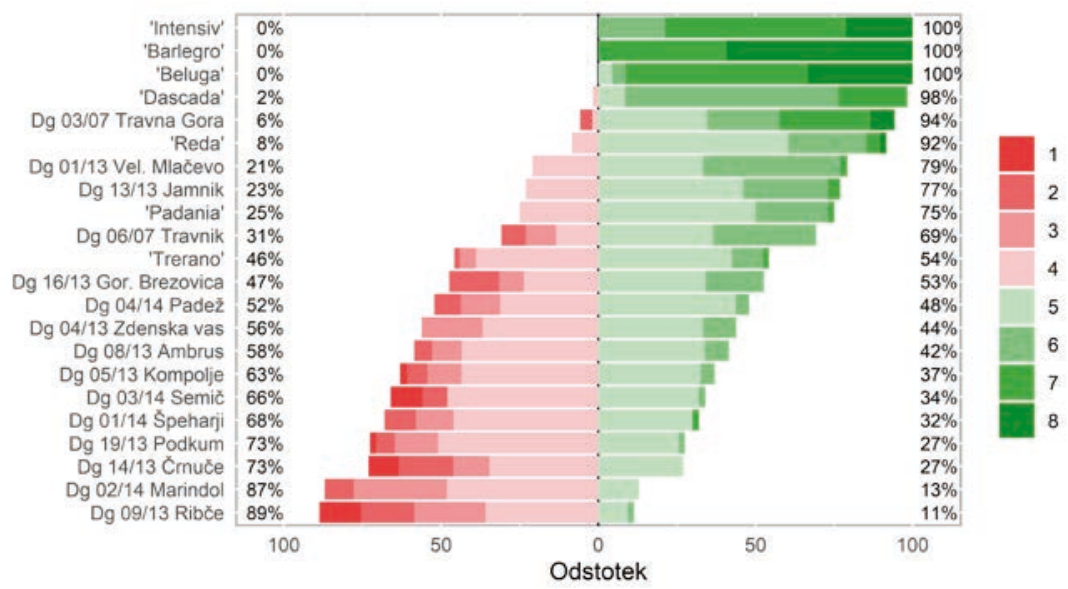

Slika 3: Pogostnostna porazdelitev ocen zgodnosti po posameznih ekotipih in standardnih sortah navadne pasje trave $(n=20)$. Zgodnost je bila ocenjena $\mathrm{z}$ razvojno fazo "Začetek latenja«, pomladi 2016. Ocene: 1 (zelo zgodnja) do 8 (zelo pozna).

Figure 3: Frequency distribution of the earliness estimates by individual ecotypes and standard varieties of cocksfoot $(n=20)$. The development earliness was estimated by means of development stage »ear emergence« in spring 2016. Estimates: 1 (very early) to 8 (very late).

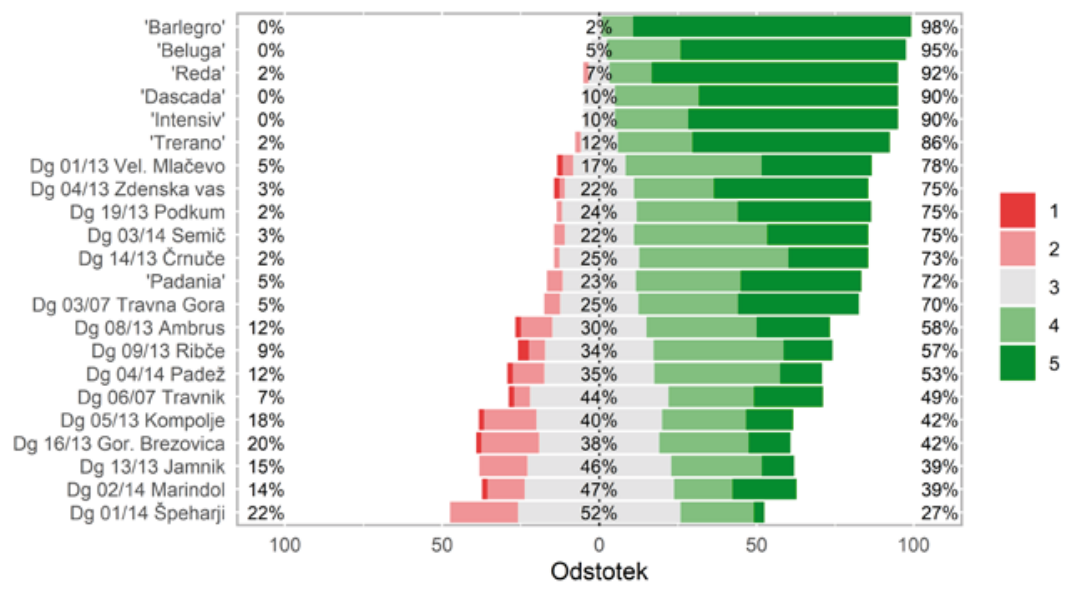

Slika 4: Pogostnostna porazdelitev ocen regeneracije po posameznih ekotipih in standardnih sortah navadne pasje trave $(n=20)$. Ocenjevanje regeneracije rastlin po poletni defoliaciji je bilo opravljeno 10. julija 2017. Ocene: 1 (zelo slaba) do 5 (zelo dobra regeneracija).

Figure 4: Frequency distribution of the regeneration estimates by individual ecotypes and standard varieties of cocksfoot $(n=20)$. The estimation of plant regeneration after summer harvest was conducted on July 10 2017. Estimates: 1 (very poor) to 5 (very good regeneration).

sortami (Slika 8), kar smo glede na rezultate preučevanih lastnosti tudi pričakovali. Velika podobnost sort je posledica žlahtnjenja, katerega cilji so bili v vseh primerih enaki - vzgoja sort, primernih za zmerno celinsko podnebje in srednje intenzivno rabo. Podobnost ekotipov je znatno manjša od podobnosti sort. Predvsem odstopajo v smeri druge glavne komponente štirje ekotipi, za katere pa ni bila ugotovljena neka skupna posebnost glede izvora. Za to skupino, ki jo sestavljajo ekotipi 'Ambrus', 'Črnuče', 'Kompolje' in 'Ribče', je bila v celoti značilna poudarjena generativna rast izven njene običajne sezone. Poleg tega sta bila ekotipa 'Kompolje' in 'Ambrus' zelo občutljiva za listne bolezni, ekotipa 'Črnuče' in 'Ribče' pa najbolj pokončne rasti med vsemi ekotipi. Vse te tri lastnosti so povzročile odmik navedenih ekotipov od drugih, kar ponazarjata smer in dolžina vektorjev.

Pri primerjavi ekotipov je zanimivo, da selekcijski pritisk, vezan na rodovitnost tal, ni bil tako velik, da bi povzročil grupacijo glede na vlažnost rastišča - vsaj med skrajnima skupinama na svežih in izrazito suhih tleh. Geografska oddaljenost izvornih lokacij ekotipov, ki v našem primeru ni bila velika, je ključnega pomena za na- 


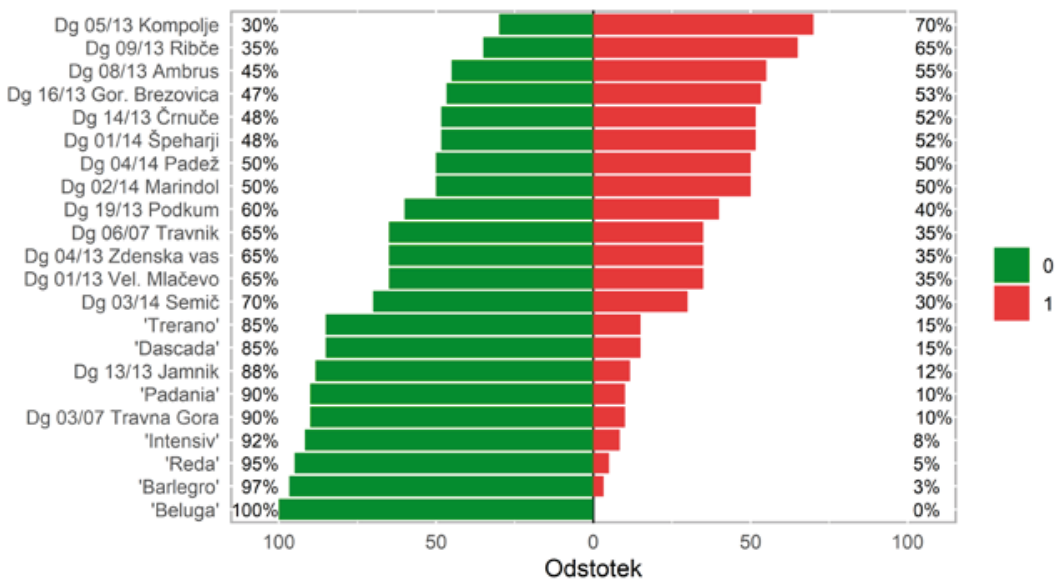

Slika 5: Pogostnostna porazdelitev prisotnosti generativnih poganjkov po posameznih ekotipih in standardnih sortah navadne pasje trave $(n=20)$. Popis je bil opravljen 26. septembra 2016. Oceni: 0 (brez), 1 (z generativnimi poganjki).

Figure 5: Frequency distribution of the presence of reproductive tillers by individual ecotypes and standard varieties of cocksfoot $(n=20)$. The estimation was conducted on September 26 2016. Estimates: 0 (without), 1 (with reproductive tillers).

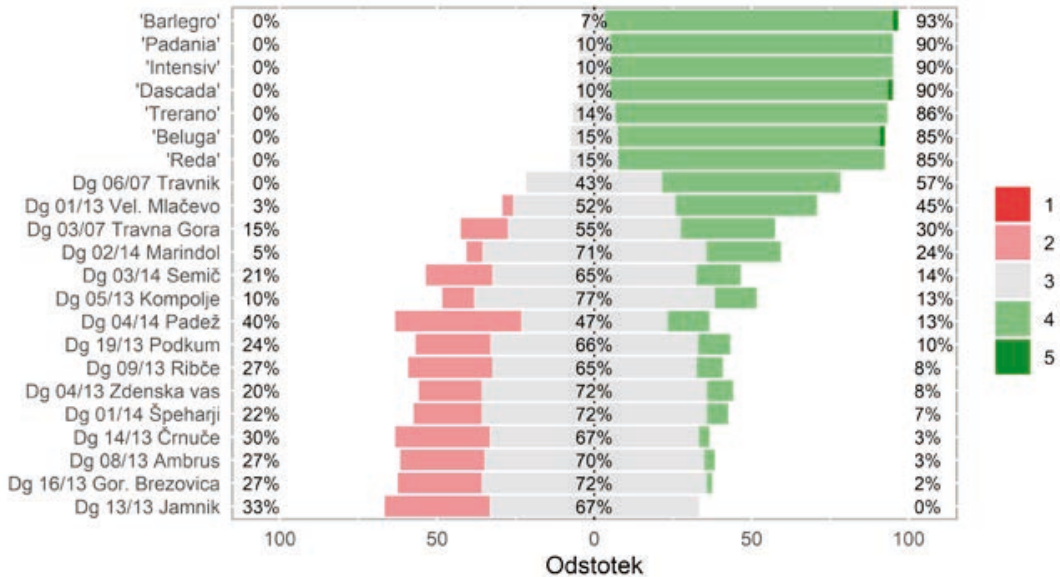

Slika 6: Pogostnostna porazdelitev ocen vigorja po posameznih ekotipih in standardnih sortah navadne pasje trave $(n=20)$. Ocenjevanje je bilo opravljeno ob koncu 6. rastne sezone, 18. novembra 2019. Ocene: 1 (slab) do 5 (zelo dober rastni vigor).

Figure 6: Frequency distribution of the vigour estimates by individual ecotypes and standard varieties of cocksfoot $(n=20)$. The estimation was conducted at the end of the 6th growth season on the November 18 2019. Estimates: 1 (poor) to 5 (very good growth vigour).

stanek genetsko in fenotipsko različnih ekotipov. Izjema se pri tem lahko pojavi, če so pridelovalne razmere zelo različne. Tak primer so švicarske populacije navadne pasje trave, ki so izvirale iz razmeroma bližnjih lokacij trajnega travinja (velikost območja $12 \mathrm{~km}^{2}$ ), a je bila na njih pridelava krme različno intenzivna (Last in sod., 2014).

\section{ZAKLJUČKI}

Preučili smo raznolikost in agronomsko vrednost na novo nabranih slovenskih ekotipov navadne pasje trave. Pri tem smo kot standard uporabili kakovostne evropske sorte, namenjene za gojenje v zmerno celinskem podnebnem pasu, kamor spada tudi večji del Slovenije.

Med obravnavanimi entitetami so bile ugotovljene značilne razlike $\mathrm{v}$ vseh preučevanih agro-bioloških lastnostih. Značilne razlike so bile ugotovljene tudi pri primerjavi skupine ekotipov s skupino sort razen v okuženosti z listnimi boleznimi. Pri tem so bile $\mathrm{z}$ agronomskega vidika sorte boljše kot ekotipi. Znotrajpopulacijska raznolikost ekotipov v preučevanih lastnostih je bila večja kot tista pri sortah. Na njo je tudi odpadel večji del skupne variabilnosti ekotipov.

Žlahtnjenje navadne pasje trave se je odrazilo v manjši medsebojni raznolikosti sort $\mathrm{v}$ primerjavi $\mathrm{z}$ med- 


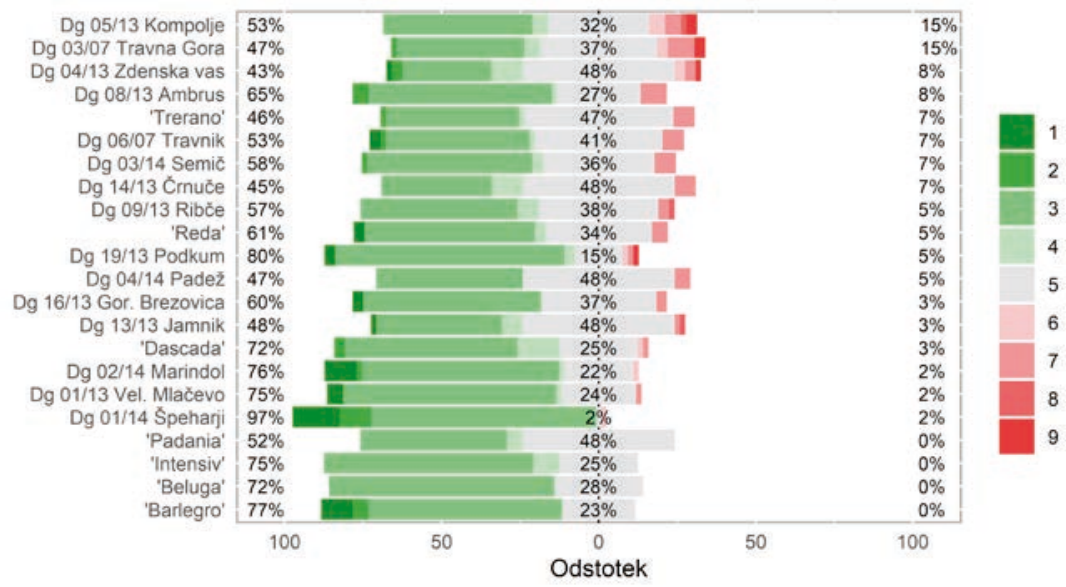

Slika 7: Pogostnostna porazdelitev ocen okuženosti z listnimi boleznimi po posameznih ekotipih in standardnih sortah navadne pasje trave $(n=20)$. Ocenjevanje je bilo opravljeno 1. avgusta 2016. Ocene: $1(1-5 \%)$ do 9 (76-100 \% pokritost listnih ploskev s simptomi).

Figure 7: Frequency distribution of the estimates of the infection with leaf fungal diseases by individual ecotypes and standard varieties of cocksfoot $(n=20)$. The estimation was conducted on the August 12016 . Estimates: 1 (1-5 \%) to 9 (76-100 \% leaf blade cover by symptoms).

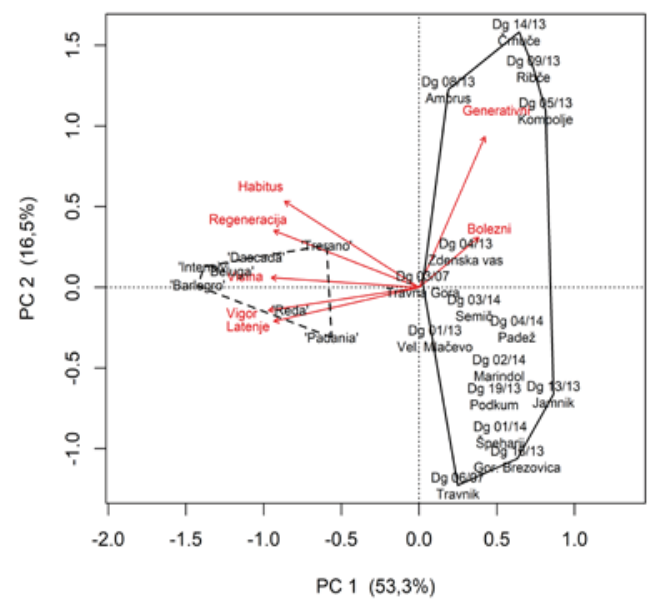

Slika 8: Rezultati analize glavnih komponent. Prikaz 15 slovenskih ekotipov in 7 standardnih sort navadne pasje trave skupaj z vektorsko težo obravnavanih lastnosti v dvorazsežnem prostoru glavnih komponent.

Figure 8: Results of principal component analysis. Arrangement of 15 Slovene ecotypes and 7 standard varieties together with the weight vectors for all investigated traits in $2 \mathrm{D}$ dimensional space of two main components

sebojno raznolikostjo ekotipov. Sorte so kot skupina tudi izrazito odstopale od skupine ekotipov. Čeprav sta kot rezultat analize glavnih komponent nastali dve podskupini ekotipov, za to nismo ugotovili nobenega $\mathrm{z}$ izvorom povezanega vzroka.

Velika znotraj populacijska raznolikost ekotipov navadne pasje trave bogati biotsko raznolikost travniških ekosistemov in izboljšuje njihovo funkcionalnost. To velja tudi za druge vrste. Genetsko razno- liki ekotipi so nujni tudi za žlahtniteljski napredek pri vzgoji novih sort, saj so posamezni genotipi vir potencialno koristnih alelov, ki pri sortah več niso prisotni.

Raziskava je bila izvedena v okviru »Javne službe nalog rastlinske genske banke «, ki jo financira Ministrstvo za kmetijstvo, gozdarstvo in prehrano R Slovenije. Tehnično izvedbo poljskega poskusa je vodil Boštjan Medved Karničar. 


\section{$5 \quad$ VIRI}

AGFF. (2017). Standardmischungen für den Futterbau Revision 2017-2020. Agrarforschung Schweiz, 8, 1-16.

Bolaric, S., Barth, S., Melchinger, A. E., \& Posselt, U. K. (2005). Molecular genetic diversity within and among German ecotypes in comparison to European perennial ryegrass cultivars. Plant Breeding, 24, 257-262. https://doi. org/10.1111/j.1439-0523.2005.01108.x

Boller, B., \& Greene, S. L. (2010). Genetic Resources. In: B. Boller, U. K. Posselt \& Veronesi F. (Eds.), Fodder Crops and Amenity Grasses (pp. 13-37). New York, Springer-Verlag. https://doi.org/10.1007/978-1-4419-0760-8_2

Boller, B., Peter-Schmid, M. K. I., Tresch, E., Tanner, P., \& Schubiger, F. X. (2009). Ecotypes of Italian ryegrass from Swiss permanent grassland outperform current recommended cultivars. Euphytica, 170, 53-65. https://doi. org/10.1007/s10681-009-9963-y

Čop, J., Lavrenčič, A., \& Košmelj, K. (2009). Morphological development and nutritive value of herbage in five temperate grass species during primary growth: analysis of time dynamics. Grass Forage Science, 64,122-31. https://doi. org/10.1111/j.1365-2494.2008.00676.x

DLG (Deutsche Landwirtschafts-Gesellschaft). (1997). DLGFutterwerttabellen - Wiederkäuer. 7., erweiterte und überarbeitete Auflage. Frankfurt am Main, DLG-Verlag.

Fehr, W. (1991). Principles of cultivar development: Theory and technique. Agronomy Books. 1. URL https://lib.dr.iastate. edu/agron_books/1

IPGRI (International Plant Genetic Resources Institute). (1985). Forage grass descriptors. Rome. URL https://www. bioversityinternational.org/fileadmin/user_upload/Descriptors_Forage_Grass.pdf

Last, L., Herzog, F., Boller, B., Widmer, F., \& Kölliker, R. (2011). Influence of habitat and management on genetic diversity of Dactylis glomerata in Switzerland. In: E. M. Pötsch, B. Krautzer \& Hopkins A. (Eds.), Grassland farming and land management systems in mountainous regions (Grassland Science in Europe, 16) (pp. 562-564). Gumpenstein, Austria. https://doi.org/10.1016/j.ecolind.2013.11.004

Last, L., Lüscher, G., Widmer, F., Boller, B., \& Kölliker, R. (2014). Indicators for genetic and phenotypic diversity of Dactylis glomerata in Swiss permanent grassland. Ecological Indicators, 38, 181-191. https://doi.org/10.1186/1471-215614-102
Last, L., Widmer, F., Fjellstad, W., Stoyanova, S., \& Kölliker, R. (2013). Genetic diversity of natural orchardgrass (Dactylis glomerata L.) populations in three regions in Europe. BMC Genetics, 14, 1-13. https://doi.org/10.1186/1471-2156-14102

Lindner, R., \& Garcia, A. (1997). Genetic differences between natural populations of diploid and tetraploid Dactylis glomerata ssp. izcoi. Grass and Forage Science, 52, 291-297. https://doi.org/10.1111/j.1365-2494.1997.tb02359.x

Martinčič, A., Wraber, T., Jogan, N., Podobnik, A., Turk, B., Vreš, B., Ravnik, V., Frajman, B., Strgulc Krajšek, S., Trčak, B., Bačič, T., Fischer, M. A., Eler, K., \& Surina, B. (2007). Mala flora Slovenije: ključ za določanje praprotnic in semenk. Tehniška založba Slovenije.

McGrath, S. K. (2008). The characterisation of genetic diversity of a collection of perennial ryegrass (Lolium perenne L.). Thesis (367 p.), Trinity College (Dublin, Ireland), Department of Botany. URL http://hdl.handle.net/2262/86495

Pagnotta, M. A., Annicchiarico, P., Farina, A., \& Proietti, S. (2011). Characterizing the molecular and morphophysiological diversity of Italian red clover. Euphytica, 179, 393 404. https://doi.org/10.1007/s10681-010-0333-6

R Core Team. (2019). R: A language and environment for statistical computing. R Foundation for Statistical Computing, Vienna, Austria. URL https://www.R-project.org/

Suter, D., Hirschi, H., Frick, R., \& Aebi, P. (2013). Knaulgras: Prüfergebnisse von 31 Sorten. Agrarforschung Schweiz, 4, 324-329. https://doi.org/10.1007/978-3-531-19729-6_4

Tuna, M., Khadka, D. K., Shrestha, M. K., Arumuganathan, K., \& Golan-Goldhirsh, A. (2004). Characterization of natural orchardgrass (Dactylis glomerata L.) populations of the Thrace Region of Turkey based on ploidy and DNA polymorphisms. Euphytica, 135, 39-46. https://doi.org/10.1023/ B:EUPH.0000009537.08697.4e

UPOV (The International Union for the Protection of New Varieties of Plants). (2002). Guidelines for the conduct of tests for distinctness, uniformity and stability. Cocksfoot (Dactylis glomerata L.). Geneva. URL https://www.upov. int/edocs/tgdocs/en/tg031.doc

Xie, W. G., Lu, X. F., Zhang, X. Q., Huang, L. K., \& Cheng, L. (2012). Genetic variation and comparison of orchardgrass (Dactylis glomerata L.) cultivars and wild accessions as revealed by SSR markers. Genetics and Molecular Research, 11, 425-433. https://doi.org/10.4238/2012.February.24.1 